REVIEW OF HISTORICAL SCIENCES 2018, VOL. XVII, NO. 3

http://dx.doi.org/10.18778/1644-857X.17.03.03

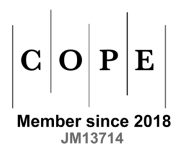

MARCIN JANAKOWSKI

Maria Curie SkŁodowska Univeristy in Lublin*

\title{
Between facts and panegyrics. Tracing the youth and peregrinations of Hieronim, Jan and Stanisław Easki
}

Summary. Research interest in the Łaski family of Korab coat of arms resulted in an array of interesting works and several times more postulates and research queries. Studies from the turn of the $19^{\text {th }}$ and $20^{\text {th }}$ century need to be updated and completed. This concerns both the factual issues and interpretational ones. In his article the author undertakes to accomplish these postulates in relation to the period of education and peregrinations of three representatives of the family from Łask: Hieronim, Jan and Stanisław, sons of Jarosław and Zuzanna of Bakowa Góra and nephews of chancellor and primate Jan Łaski. Apart from reconstructing some events, the author reinterpreted the preserved source material and juxtaposed the results with the previous state of research. This resulted in identifying some inaccuracies reproduced for decades or statements unconfirmed by any sources which are deep rooted in the historiography.

Keywords: Łaski, peregrination, study, Bologna, Venice.

he researcher exploring the past world through the prism of preserved sources is, in a sense, a slave to chance since

1 it is not known what type of materials will stand the test of time and which will be damaged or dispersed to the extent that it is impossible to use them. Such obstacles are especially faced by researchers who wish to present the youth of historical figures presented in their works. So as to establish the time of their birth, the atmosphere in their family house or their education, i.e. all the elements which in fact determine the following years of their life, it is necessary to have sources of both private and school as

${ }^{*}$ Faculty of Humanities, Institute of History, Department of History of $16^{\text {th }}-18^{\text {th }}$ Century / Wydział Humanistyczny, Instytut Historii, Zakład Historii XVI-XVIII wieku, e-mail: marcin.janakowski@wp.pl. 
well as university provenance. In the vast majority of cases the lack of such material prevents them from sketching anything more than just a general outline of the epoch and locating the presented figure within this framework. Despite this it is sometimes possible to break through this pessimistic picture of historiography and readers obtain a more complex picture of youth, education and upbringing of individuals living in earlier times due a detailed query and subsequent thorough research of historians ${ }^{1}$.

It seems that such possibilities are offered to researchers by the preserved source material concerning the Laski family. This high-profile name in the $16^{\text {th }}$ century of a magnate family of Korab coat of arms from Sieradz attracted attention of both their future supporters and critics ${ }^{2}$. As a result, there are many studies devoted to members of the Laski family ${ }^{3}$. The value of these works and

${ }^{1}$ It is worth making a reference to such works as: M. Chachaj, O dacie urodzenia $i$ edukacji hetmana Jana Karola Chodkiewicza, [in:] Studia z dziejów Wielkiego Księstwa Litewskiego (XVI-XVIII wieku), eds S. Górzyński, M. Nagielski, Warszawa 2014, pp. 49-59; W. Kłaczewski, Jerzy Ossoliński. Wielki kanclerz Rzeczypospolitej, Lublin 2011, pp. 29-45; Z. Trawicka, Jakub Sobieski (1591-1646). Studium $z$ dziejów warstwy magnackiej $w$ Polsce doby Wazów, Kraków 2007, pp. 25-41; M. Chachaj, Młodość Michała Tomasza Korybuta Wiśniowieckiego przyszłego króla polskiego, 'Czasy Nowożytne' 2015, vol. XXVIII, pp. 95-110; A. Witusik, Młodość Tomasza Zamojskiego. O wychowaniu i karierze syna magnackiego $w$ pierwszej połowie XVII wieku, Lublin 1977, passim.

${ }^{2}$ Interest in the representatives of the Laski family was already expressed by Szymon Starowolski in his work devoted to the greatest 'Sarmatian warriors'. See S. Starowolski, Sarmatiae Bellatores, Kolonia 1631, pp. 182-186. Jakób Unieszowski living at the turn of the $16^{\text {th }}$ and $17^{\text {th }}$ century devoted an extremely interesting poem to the Korab family. See J. Unieszowski, Evdimonia Olbrichta Laskiego woiewodi siradzkiego, Kraków 1609. Likewise, they were not overlooked by Bartosz Paprocki, the first Polish heraldist after Jan Długosz. See Herby rycerstwa polskiego przez Bartosza Paprockiego zebrane i wydane r. p. 1584, ed. K.J. Turowski, Poznan 1859, pp. 586-590. The works quoted do not contain any information either on the youth or education of the Łaskis, making references mainly to their greatest achievements, including those rather legendary ones.

${ }^{3}$ Among numerous studies devoted to members of the Laski family it is worth mentioning those of biographical character. In the case of primate Jan Laski these will certainly be Jan Łaski. Arcybiskup gnieźnieński sprzymierzeńcem sułtana tureckiego. Szkic historyczny, Lwów 1879 by Aleksander Hirschberg or Jan Łaski (1456-1531) kanclerz koronny i prymas Polski, Warszawa 2007 by Piotr Tafiłowski. There is one more extensive study on Stanisław Laski, the castellan of Przemęt and later the voivode of Sieradz: Stanisława Łaskiego wojewody sieradzkiego prace naukowe $i$ dyplomatyczne, ed. M. Malinowski, Wilno 1864. Researchers wrote most frequently on the life and activities of Jan Łaski, the archbishop of Gniezno, one of the leading European reformers. It is worth quoting here such works as: P. Bartels, Johanes a Lasco, Elberfeld 1860; H. Dalton, Johannes 
their up-to-datedness may be disputable, however, particularly in relation to the youth and course of education. The reader may feel disappointed in this respect by the lack of information or the fact that well-worn theses are regurgitated, without any attempt to verify them on the basis of the preserved source material. Statements which are unconfirmed or contradictory to sources permeate even the recent literature of the subject. The Laskis appearing on margins of broader studies were associated with education which they never obtained or places which they never visited or, on the contrary, a number of facts about their life was skipped. It seems, though, that having access to quite an extensive source material, as in this case, requires special attention and insight since this is an extraordinary situation, allowing to shed a little more light on the upbringing and peregrinations of young representatives of magnates at the beginning of the $16^{\text {th }}$ century.

Bearing the above in mind, it is noteworthy to conduct critical analysis and interpretation of the source material and then verify the existing views on the youth and education of the squires of Łask. Perhaps the effort invested in it will allow to systematise the knowledge we possess, fill the existing gaps and present a coherent picture of the youth and peregrinations of Hieronim, Jan and Stanisław Łaski which is confirmed by the sources.

\section{Common years}

Beginning the considerations on the early years of the descendants of Jarosław Łaski and Zuzanna of Bakowa Gora, it is worth pointing clearly to the historical figures of this article. This seemingly obvious postulate in historiography did not always remain without discussion. Relying as a rule on solid sources, in his fundamental work Rev. Jan Ignacy Korytkowski suggested that a Jarosław should be added to the siblings of Hieronim, Jan and Stanisław ${ }^{4}$.

a Lasco Beitrag zur Reformationsgeschichte Polens Deutschlands und Englands, Gotha 1881 or O. Bartel, Jan Easki, part 1 (1499-1556), Warszawa 1955. The first and only so far biography of Hieronim Laski was written by A. Hirschberg, Hieronim Easki, Lwów 1888. It is also worth mentioning the text devoted to Olbracht Łaski, an equally high-profile descendant of Hieronim - A. Kraushar, Olbracht Łaski wojewoda sieradzki. Wizerunek historyczny na tle dziejów Polski XVI wieku, Warszawa-Kraków 1882.

${ }^{4}$ J. Korytkowski, Prałaci i kanonicy katedry metropolitalnej gnieźnieńskiej od roku 1000 do dni naszych, vol II, Gniezno 1883, pp. 499-501. 
One justification for this thesis was the occurrence of two figures in some sources, i.e. Hieronim and Jarosław of Łask, in whom the author saw two different people. Still in the $19^{\text {th }}$ century this evident mistake was spotted by Aleksander Hirschberg, a researcher from Lviv. Quoting onomastic works by Antoni Małecki ${ }^{5}$ and an array of sources referred to by Rev. Korytkowski, he unequivocally merged the figure of Hieronim and Jarosław, explaining this by differences in the Latin and Polish versions of the same name ${ }^{6}$. Fortunately, the subsequent researchers did not suggest any other connections between the Laski siblings and till this day the literature of the subject enumerates Hieronim, Jan and Stanisław as the sons of Jarosław of Lask, who are the subject of considerations in this article.

\section{a) Family nest - Lask}

According to all premises it may be clearly stated that Hieronim was the first-born son of Jarosław Laski and Zuzanna of Bakowa Góra ${ }^{7}$. The exact date of his birth, September 27, 1496, was first indicated by A. Hirschberg. ${ }^{8}$. This proposal was commonly accepted by different researchers who referred to the figure of Laski, and there are no alternative proposals today ${ }^{9}$ Jan was born as second, probably in 1499, which is supposed to be confirmed by the protocol of the Synod of Pińczów of January 29, $1560^{10}$. As this is probably the only record allowing to identify the date of birth of Jan, researchers treated it with due distance ${ }^{11}$. In contrast, the date of

${ }^{5}$ A. Małecki, Gramatyka historyczno-porównawcza języka polskiego, vol. I, Lwów 1879, p. 81.

${ }^{6}$ A. Hirschberg, Hieronim Easki..., p. 5.

${ }^{7}$ In his youth he probably used the original version of his name, i.e. Jarosław. I adopted the uniform name form of Hieronim in order to make it uniform and differentiate him from his father.

${ }^{8}$ A. Hirschberg, Hieronim Easki..., p. 5.

${ }^{9}$ W. Urban, Easki Hieronim, [in:] Polski słownik biograficzny [hereinafter: PSB], vol. XVIII, Wrocław 1973, p. 225.

${ }^{10}$ Akta synodów różnowierczych $w$ Polsce, vol. II (1560-1570), elaboration M. Sipayłł, Warszawa 1972, p. 8.

${ }^{11}$ H. Dalton, op. cit., p. 28; idem, John a Lasco. His earlier life and Labours, transl. J. Maucrice, B. Evans, London 1886, p. 30; Herbarz Polski, part 1 (Wiadomości historyczno-genealogiczne o rodach szlacheckich), eds A. Boniecki, A. Reiski, vol. XV, Warszawa 1912, p. 192; H. Kowalska, Easki Jan, [in:] PSB, vol. XVIII, Wrocław 1973, p. 237. 
birth of the youngest brother, Stanisław, remains a mystery. So far it has been assumed that he was born at the turn of the $15^{\text {th }}$ and $16^{\text {th }}$ century, though not documenting this fact in any way ${ }^{12}$. One may attempt to verify it only on a basis of a certain trace, as none of the known sources gives an unambiguous answer to this question.

Certain information concerning the age of Stanisław was included in a letter written by Erasmus of Rotterdam to Jan Maldonatus, a Spanish theologian. Mentioning his relations with Jan Laski the Younger, he wrote to the recipient of his letter that he had an elder brother Hieronim, a voivode, and a younger one Stanisław, 'a boy of great expectations" ${ }^{13}$. Taking into account that the letter was written on March 30, 1527, the notion 'adolescentus' used by Erasmus allows to presume that Stanisław was much younger than his brothers. The scholar must have been aware of the age of the Łaski brothers as having met all of them in person, he maintained a long-standing relationship with them ${ }^{14}$. It is true that writing these letters, Erasmus himself was a mature man and his understanding of a 'youngster' could have been far more extensive. He also referred to Jan the Younger as a lad, for instance in his letter to Krzysztof Szydłowiecki of August 14, $1525^{15}$. In this case, the context of the letter is very emblematic. Calling Jan taski a youngster differentiates him from his paternal uncle and namesake. It also shows certain attitude of Erasmus to Łaski, who he treated as his student and favourite ${ }^{16}$. There seems to be no similar intimacy in his contacts with Stanisław.

${ }^{12}$ Referring to the date of birth of Stanisław, Mikołaj Malinowski used quite an enigmatic description: 'towards the very end of the $15^{\text {th }}$ century'. See Stanistawa Łaskiego Wojewody Sieradzkiego prace naukowe..., p. XVI. Janusz Sikorski claimed, in turn, that he was born around the year 1500. See J. Sikorski, Easki Stanisław, [in:] PSB, vol. XVIII, Wrocław 1973, p. 253.

${ }^{13}$ Opus epistolarum Des. Erasmi Roterodami, ed. H.M. Allen, vol. VII (15271528), Oxford 1928, p. 17.

${ }^{14}$ One testimony of long-standing contacts of Erasmus of Rotterdam with the Laski family is their preserved correspondence which the humanistic scholar maintained with the magnates of Łask from 1524 till the end of his life. See Korespondencja Erazma $z$ Rotterdamu $z$ Polakami, transl. and elaboration M. Cytowska, Warsaw 1965, No. I; V; IX; XI; XIII; XXIII; XXVI; XXXI; XXXVI; LXXI; LXXIII; LXXVI; LXXVIII.

${ }^{15}$ Ibidem, No. III.

${ }^{16}$ The emotional approach of Erasmus of Rotterdam to Jan Łaski is manifested in many letters and dedications of the great humanist. Being at his house, taski was generous at supporting his mentor financially in return of his schooling and the possibility of remaining in his company. He is normally, however, referred to 
Another argument pointing to the later birth of Stanisław may be the fact that he did not hold any, if purely honorary, court function or office until 1534, which used to be a typical element of the career of crown magnates ${ }^{17}$. As for his presence in the sources, it should be mentioned that the first document suggesting Stanisław's maturity does not appear until 1523 when together with his brothers and paternal uncle he was released of custody of Anna, the daughter of Jakub Glinka ${ }^{18}$. It is also puzzling that, unlike his brothers, he is not mentioned in primate Łaski's financial documents. Notwithstanding that he was not completely overlooked by his paternal uncle ${ }^{19}$. Perhaps this may be also associated with longer nonage than in the case of his brothers and the fact of remaining under the custody of his father. Jarosław Laski, the voivode of Sieradz, probably died in $1521^{20}$. After his death elder Hieronim took over, in a sense, the custody of his brother who will become his long-standing companion and confidant. The above-mentioned premises do not provide an answer to the question about Stanisław's date of birth, they allow to suppose, however, that the age gap between Stanisław and the other brothers was about a few years bigger than it was originally thought, which affects the perception of a number of ambiguities in his biography.

Likewise, it is complicated to determine the place of birth of Jarosław Łaski's descendants. The first historian who came up with a concrete proposal was Hermann Dalton. His choice was Łask, their family nest, and as one may suppose, it was approved of different researchers who were willing to reproduce these findings ${ }^{21}$. There

with the notion of iuvenis, or youth, rather than adolescentus, which could point to a person who is underage or immature.

${ }^{17}$ Stanisław's first office was the castellany of Przemęt which he did not obtain until 1534. See Urzędnicy wielkopolscy XVI-XVIII wieku. Spisy, elaboration A. Bieniaszewski, Wrocław 1987, No. 1063, p. 152.

${ }_{18}$ Archiwum Główne Akt Dawnych w Warszawie / The Central Archive of Historical Records in Warsaw [hereinafter: AGAD], Metryka Koronna / The Crown Metrica [hereinafter: MK] 37, sheet 453.

${ }^{19}$ At the request of the primate, Stanisław and his brothers gained the right of patronage of St George's church on the castle in Gniezno on August 6, 1521. See AGAD, MK 37, sheet 212. Two years later, also at the request of the primate, the Laskis gained the right of patronage of both the church and the canonry in Klecko. See ibidem, sheet 500v.

${ }^{20}$ S.M. Zajączkowski, Łaski Jarosław, [in:] PSB, vol. XVIII, Wrocław 1973, pp. 244-245.

${ }^{21}$ The following researchers were willing to accept the birth of Jarosław's descendants in ancestral Łask: J. Korytkowski, op. cit., p. 499; O. Bartel, 
would have been nothing wrong with that had the author supported his hypothesis with some sources or at least presented a credible premise. There was also no reference in the description of the early years of Jan, in which $\mathrm{H}$. Dalton used very poetic forms, situating that time into some general concept of the epoch. It is difficult to interpret such statements in a different way as the boy [Jan] spent his childhood here [in Lask] in a beautifully located castle in the company of his parents, brothers and sisters. Polish children then were raised in great fear and respect of their father and mother... ${ }^{22}$. Already in this fragment it is easy to notice some generalisations. Adding to this the author's beliefs on 'their family house filled with noise', one may doubt the reliability of his findings. It is worth pointing out that the aforementioned family house in Lask was not the only residence of Jarosław and his spouse. As a result of a beneficial marriage the financial position of Laski improved considerably. He became owner of numerous estates in Greater Poland, including Bakowa Góra, Osin or Będzin. Consequently, one may not restrict the residence of the spouses solely to Lask. Dalton's findings taken for granted by many researchers tend to have more in common with a certain vision of how people of the given epoch functioned rather than reliable arguments. At the same time it must be pointed out that this proposal cannot be altogether excluded for the same reasons why it seems impossible to confirm it today.

\section{b) At the court of their paternal uncle}

Where and how did the sons of Jarosław, the Castellan of Inowrocław, spend their early years? One may, following the example of Dalton, point to certain general upbringing models of young boys and relate them to the biography of the Laskis. It is worth, nevertheless, highlighting certain facts which give a more detailed picture of the early period of their life. Their paternal uncle, Jan Łaski the Elder, was a guardian and real support for Hieronim, Jan and Stanisław. The relations of the boys with their father and mother are almost

op. cit., p. 13; W. Urban, Easki Hieronim..., p. 225; J. Sikorski, op. cit., p. 253. This place was indicated with far more scepticism by A. Hirschberg, Hieronim Easki..., p. 5.

${ }^{22}$ H. Dalton, op. cit., p. 29. 
completely unknown for researchers ${ }^{23}$. It was the chancellor, and subsequently the primate, that dealt with rearing and educating them. It seems that some authors are right in seeing in Jan the Elder 'the head' of the family setting paths of development for his relatives. His personal spectacular promotion clearly affected both his closer and more distant family. If the circle of beneficiaries of his political and social activity still requires more in-depth research, then it may be generally concluded, paraphrasing the words by Henryk Sienkiewicz, that the rise in his fortune was accompanied by a rise in other fortunes. This also concerned his brother Jarosław, who was supported by the primate on a number of occasions ${ }^{24}$.

As it may be presumed, the chancellor cared about the prosperity of his family whose future were his nephews. He expressed his attitude to them in practice, taking care of their suitable education and financial security. His activities are visible for researchers particularly in the education period of Łask heirs, nevertheless there are also some clues which allow to shed more light on earlier years. In his diary, which was fortunately preserved till this day, Jan Łaski included a thought which was creatively developed by many researchers ${ }^{25}$. The primate wrote this with reference to financial support for Hieronim during one of his journeys in 1518: 'z miłości dla niego [Hieronima] zapłacę zażądaną sumę, gdyż od dzieciństwa wychowując go, utrzymywałem tak w domu jak i za granica i byłoby rzecza niegodna opuścić go w ostatniej chwili jego podróży [...]' [out of my love for him (Hieronim) I shall

${ }^{23}$ The only set of information concerning Jarosław of Łask is an article devoted to him by Stanisław Marian Zajączkowski. See S.M. Zajaczkowski, op. cit., pp. 244-245. Little is known about the spouse of Jarosław apart from her family connections and it is also difficult to determine the date of her death, which would, at the same time, make the dividing line of Stanisław's birth.

${ }^{24}$ It is particularly easy to see the financial support which Jan gave to his brother. See P. Tafiłowski, Finanse prymasa Jana Laskiego. Na podstawie raptularza $z$ Archiwum Głównego Akt Dawnych w Warszawie, 'Przegląd Historyczny' 2004, vol. XCV, issue 1, pp. 1-36.

${ }^{25}$ AGAD, Varia $z$ Biblioteki Baworowskich / Varia from Bawarowscy Library [hereinafter: BBaw], ref. code 246. The text of the diary was published in 1874 by Heinrich Ritter von Zeissberg, an Austrian historian. See H. Zeissberg, Johannes Easki Erzbischof von Gnesnen (1510-1531) und sein Testament, [in:] Sitzungsberichte der Philosophisch-Historischen Klasse der kaiserlichen Akademie der Wissenschaften, Bd. LXXVII, Hf. III, Wien 1874. Piotr Tafiłowski showed great interest in this source, using it in his works: P. Tafiłowski, op. cit.; idem, Jan Łaski (1456-1531) kanclerz koronny i prymas Polski, Warszawa 2007. 
pay the sum ordered as rearing him from his childhood I aided him both at home and abroad and vile it would be to desert him in the last moment of his journey (...) $]^{26}$.

The character of the diary, which is composed of personal notes, makes it a reliable source. It is visible in the light of this comment that the primate's custody of his nephew was long-term. Holding the function of the Grand Chancellor of the Crown since 1503, Łaski resided in the capital of Cracow, except his legation missions and journeys in the royal retinue. One may presume that wishing to see to the development of his nephews, he placed them by his side in the capital. He was able to provide them there not only with personal care but also suitable tutors and teachers. It is not known, however, since when and if all the three brothers stayed in Cracow. Their possible stay there was quite exuberantly extended in the work by H. Dalton. Pondering on the tutors and schooling which they could have received in connection with the university functioning there, he created a detailed picture of education in the capital $^{27}$. One year after the publication of the work by the German author, it was criticised by Wincent Zakrzewski, who rightly noticed that Dalton did not have any basis for writing so much about 'the Cracow period' of the young Łaski brothers ${ }^{28}$.

The fact that the brothers stayed in Cracow in the chancellor's custody was evident to most researchers. It is known, though, that their stay was not connected with studying at the university there. None of them appeared in the records of Cracow University. This does not exclude the possibility of taking private lessons and schooling under the watchful eye of Cracow university lecturers.

\section{c) First peregrinations}

Travelling abroad to explore foreign languages, customs, law, history, philosophy and general information about the world was gaining greater and greater popularity in the course of the $16^{\text {th }}$ century as a way of obtaining education. For this reason staying at the university did not

${ }^{26}$ AGAD, BBaw, ref. code 246, sheet 38.

${ }^{27}$ H. Dalton, op. cit., pp. 48-50.

${ }^{28}$ W. Zakrzewski, Rodzina Easkich $w$ XVI wieku. II. Synowcowie prymasa: reformator Jan Łaski i jego bracia Hieronim i Stanisław, 'Ateneum' 1882, vol. IV, p. 554. 
always equal receiving a scientific degree and, similarly, a journey did not have to mean visiting one university ${ }^{29}$. Understanding the spirit of that model of education seems indispensable for the interpretation of the preserved sources as it was in this spirit that the Laski brothers received their schooling.

It is quite certain that their paternal uncle was the initiator of their peregrinations. At the peak of his career in 1510, he reached for the dignity of the Archbishop of Gniezno, becoming at the same time the Primate of the Kingdom and its first senator. New duties resulting from his post caused that in 1513 together with Stanisław Ostroróg, the castellan of Kalisz, he took part in a legation to the Council of the Lateran. Also on that occasion the primate did not forget about his nephews, taking them to Italy with him ${ }^{30}$. It was a convenient moment to initiate their real education. Having reached an adequate age and knowledge necessary for further development, Jan and Hieronim left the country in March $1513^{31}$. None of the known sources so far allows to even presume that the brothers set off with the youngest Stanisław, who as it may be alleged, stayed in his family house with his father.

Primate Łaski's retinue was probably joined by the sons of Mikołaj Radziwiłł, the voivode of Vilnius: Jan, from 1517 the cup-bearer of Lithuania, and Stanisław, later the prefect of Užpaliai and Pieniany ${ }^{32}$. The detailed route of the legation is not fully known. It may be presumed that having set out in March, the retinue headed for Silesia and then the Kingdom of Bohemia, where the primate stayed at the beginning of April 1513. During his stay in Olomouc on April 6, he drafted his will which had a notary seal

${ }^{29}$ Marian Chachaj demonstrates the functionality of this model of upbringing and education in his works. See M. Chachaj, Zagraniczna edukacja Radziwiłłów od poczatku XVI do połowy XVII wieku, Lublin 1995, p. 7.

30 The preserved sources concerning the journey of primate Łaski to Rome fail to give the full composition of his retinue. It is possible to detect the presence of the two Łaski brothers only from the perspective of the correspondence which the nephews maintained with the primate while they were in Bologna.

${ }^{31}$ The stay of the Laskis in Rome is confirmed by letters written by them as well as by other members of the retinue to the primate. See L. Gładyszewski, Korespondencja studentów bolońskich $z$ prymasem Janem Łaskim $w 1515$ roku, 'Studia Gnesnensia' 1977, vol. III, pp. 261-279.

32 There are no unambiguous sources which allow to establish with certainty whether the Radziwiłłs set off for Italy together with the Laskis or if they joined them later, having stayed in Vienna. See M. Chachaj, Zagraniczna edukacja Radziwiłtów..., p. 14. There is no indication of Jan Easki's earlier stay in the Empire's capital. 
of Pawel Planek ${ }^{33}$. Then they travelled in the direction of Vienna where Stanisław Radziwiłł and Jan Laski could have abandoned the retinue so as to study in the capital of the Empire. It is not possible to say whether it was then that the youngsters began their studies in Germany ${ }^{34}$. We only learn about the stay of the two peregrines there from the letters which primate Łaski received from his dependants ${ }^{35}$. It is known that Stanisław Radziwiłł studied in Vienna for some time before he went to Bologna. It is difficult to describe precisely the course of Jan Łaski's education. Probably still in 1513 he was staying in Leipzig where the primate, who was then in Rome, sent money for his nephew ${ }^{36}$. As it may be presumed, his stay there did not result in undertaking formal studies as young Laski's name does not appear in the preserved records of Leipzig University ${ }^{37}$.

The following confirmed stopover of the retinue was Venice where the envoys, hosted by Loredano, the doge of Venice, encouraged the Venetians to fight Turkey together. According to Włodzimierz Dworzaczek, the retinue reached the gates of the Eternal City on June $5,1513^{38}$. As a regular guest there Jan Laski the Elder was in possession of a well-organised house which was used by him and the beneficiaries of his cultural and scientific sponsorship. The chamberlain of the court there was Stanisław Borek, the dean of Cracow and the Royal Secretary. Some researchers, including Henryk Barycz and Władysław Pociecha, presumed that Borek was a graduate of Rome University and as such was certain to perfectly

${ }^{33}$ AGAD, BBaw, ref. code 246, sheet 26.

${ }^{34}$ One cannot rule out the possibility that both Jan Laski and the Radziwiłs began their peregrinations earlier and their departure should not be unequivocally connect with the primate's legation to Rome.

${ }^{35}$ L. Gładyszewski, op. cit., letters No. 3, 4, pp. 271-274.

${ }^{36}$ In his diary before 1513 the primate and his 'Rome agent', Jan Rybieński, made notes of expenditures and debts which should be paid off for the archbishopric's income. The last position of this list was: 'In Lypsk C [100] fl. Nepoti missi'. This record may be unambiguously connected with young Jan Laski, whose stay and studies in Germany are confirmed by other sources. See AGAD, BBaw, ref. code 246, sheet 26b.

${ }^{37}$ Stanisław Tomkowicz, who was at the same time the editor of records of the Polish nation of Leipzig University, wrote about Poles and the Polish nation at that university. See Metrica nec non liber nationis Polonicae Universitatis Lipsiensis ab anno 1409 usque ad 1600, ed. S. Tomkowicz, 'Archiwum do Dziejów Literatury i Oświaty w Polsce', vol. II, Kraków 1882, pp. 409-444.

${ }^{38}$ W. Dworzaczek, Łaski Jan, [in:] PSB, vol. XVIII, Wrocław 1973, p. 231. 
know the arcana of the Eternal City ${ }^{39}$. It may be presumed that it was him who took care of the youngsters who arrived in Rome with the primate ${ }^{40}$.

It remains a mystery why the young Łaskis decided to cover the first stage of the journey separately. So far no author has provided a rational reason for this phenomenon. This could be explained to some extent by primate Łaski's endeavours aimed at preparing his nephews to perform appropriate functions in the years to come. It is clear, for instance, that journeys made by Jan the Younger have a markedly more 'academic' character. It does not seem accidental that he visited Leipzig, Bologna, Rome or Padua, which are homes to renowned universities popular among foreigners. Suitable education was not also without significance for the development of church career, which was confirmed by numerous examples ${ }^{41}$. In the case of Hieronim, peregrinations assumed a more 'political' direction. The council which took place in Rome was certainly an ideal place to learn how to act in practice. Besides, the primate had an opportunity to present his nephew to many eminent dignitaries, both clerical and layman, which was one of the basis of forming a young politician. The only 'university' stopover of Hieronim was Bologna, where the primate's nephews arrived at the end of 1514 and the beginning of $1515^{42}$.

${ }^{39}$ H. Barycz, W. Pociecha, Borek Stanisław, [in:] PSB, vol. II, Kraków 1936, pp. 320-322.

${ }^{40}$ Some reminiscences from Jan's German period may be found in a letter from Hieronim Łaski to the primate in which he recalls that 'zdolność jego [Jan Łaski] i staranność, których w zwykłej mowie, a także we wszelkiej pieśni dowodzi, długo przez innych młodzieńców sa podziwiane. W okresie jego pobytu w Niemczech istotnie nie tracił czasu na liczenie piasku, a najwspanialszych autorów i słuchał, i czytał' (own translation) [other young men long his talents and precision (of Jan Łaski) laud which he in normal speech and also all kind of song proveth. During his stay in Germany never did he waste time on counting sand but the greatest authors he listened to and read]. See. Gładyszewski, op. cit., letter No. 4, p. 274.

${ }^{41}$ The time of journeys of young Łaski was a period of flourishing humanism and respect for education and knowledge. It suffices to say that excellent education was also received by church hierarchs of that time, including the bishop of Cracow, Jan Konarski (Bologna), the bishop of Przemyśl, Piotr Tomicki (Bologna), the bishop of Poznan, Jan Lubrański (Bologna, Rome) or the bishop of Warmia, Fabian Luzjański (Bologna, Ferrara).

${ }^{42}$ This arises from the letter from Jan Radziwiłł as of January 25, 1515 to the primate, who was then staying in Rome. See L. Gładyszewski, op. cit., letter No. 1, pp. 268-269. 


\section{d) Education in Bologna}

This period allows for quite a detailed recognition as compared to the previous ones. It is worth stressing that writing about the 'Bologna studies', I do not mean formal education at the University of Bologna as none of the sources confirms this ${ }^{43}$. The information on the basis of which one may construct the picture of peregrines' daily life and their surroundings is included mainly in the aforementioned correspondence related to the period between January and March 1515. Luckily, the letters in question allow to capture a certain perspective and reconstruct quite precisely the composition of the 'Polish house' and changes taking place in $\mathrm{it}^{44}$. This seems important as despite numerous references to the aforementioned sources there are still certain controversies even in more recent literature.

The first information on the arrival in the city comes from the letter from Jan Radziwiłł of January 25, 1515 to primate Łaski. Its contents allow to conclude that it was not the first letter written from Bologna since, as the author himself had mentioned, 'o zdrowiu naszym w poprzednich listach napisałem wystarczajaco' [on our health in my previous letters I wrote enough]. The fresh memory of 'benefits' which he received from Jan Laski the Elder still in Rome, indicates that the youths continued their journey precisely from the Eternal City. In his letter Radziwiłł also made references to several other people, including his brother Stanisław, who he praises for progress in learning, Jan Branicki ${ }^{45}$, the butler in their house, doctor Maciej ${ }^{46}$ who took medical care of everyone, Maciej, the preceptor of the Radziwiłls ${ }^{47}$ and Marcin, the cook, recommending them all to the mercy of the primate ${ }^{48}$. The

${ }^{43}$ This seemingly unimportant linguistic nuance caused a lot of confusion in historiography as some researchers saw in the Laskis students of Bologna University, which is evidently at odds with the sources. The correspondence which the inhabitants of the Bologna 'boarding school' exchanged with the primate, who was staying in Rome, clearly shows that lessons were organised as part of their common home, hiring the local scholars for particular subjects.

${ }^{44}$ Apart from the originals kept in the archdiocese archive in Gniezno the researchers have at their disposal two source editions of this correspondence. See W. Pociecha, Ze studiów bolońskich Jana Łaskiego, 'Reformacja w Polsce' 1926, vol. IV, pp. 144-152; L. Gładyszewski, op. cit., pp. 261-280.

${ }^{45}$ W. Pociecha, Branicki Jan, [in:] PSB, vol. II, Kraków 1936, p. 402.

${ }^{46}$ Medical care of students was probably provided by Maciej Sieprawski, medicine doctor and lector of Bologna University.

${ }^{47}$ This probably refers to Maciej Przybył. See H. Barycz, Przybyło Maciej, [in:] $P S B$, vol. XXIX, Wrocław 1986, pp. 122-123.

${ }^{48}$ L. Gładyszewski, op. cit., letter No. 1, pp. 268-269. 
second letter of Jan Radziwiłł of February 9, 1515 contains far more information particularly important for the topic in question. The reader learns about changes which took place in the house, including that of its composition and the visit paid by Mikołaj Wolski, the castellan of Sochaczew ${ }^{49}$, accompanied in Bologna by Jan Laski and Stanisław Radziwiłł. The second of the brothers was said to have appeared there with certain health problems which doctor Maciej was striving to combat. As a result from January 1515, beside the two Radziwiłłs, Bologna was home to the two Laski brothers, Hieronim and Jan, as well as Maciej Sliwnicki ${ }^{50}$ and Wilhelm Jarocki ${ }^{51}$, who dealt with the education of the dwellers ${ }^{52}$.

A few days later on February 14, Jan Branicki, the youngsters' guardian, wrote a letter to his principal. In a relatively long account he presented details concerning the functioning of the house and its dwellers. Reading the letter, one may not overlook the very detailed and prospective description of preparations which Branicki and others were making in order to ensure all the comforts in the house. Information on the purchase of equipment for learning, hygiene and leisure as well as the circumstances of buying food may be a proof that the Bologna stopover was by no means temporary since the letter was reminiscent of an account of present spending and a vision of future expenditure which will be incurred. The letter contains information about persons which were not accounted for earlier, such as Skotnicki or Jan, the provost of Płock ${ }^{53}$.

${ }^{49}$ Mikołaj Wolski was a loyal friend of the Laski family. He accompanied the primate in his journey to Rome to the Council of the Lateran. Events on the eastern borders of the Kingdom of Poland did not allow him to stay long in the Eternal City. He left Rome approximately on May 10, 1514 and began his journey back home. He took part in the victorious Battle of Orsha where he led one of the troops. After the victorious battle the king ordered him to return to Italy as an envoy to Pope Leo X. His task was to give the Head of the Church 14 Orsha captives as a sign of victory over schismatics. In accordance with the primate's request, Wolski was to make a stopover in Vienna, where Jan Łaski and Stanisław Radziwiłł were staying, and then take them to Bologna which he reached in January 1515 . See W. Pociecha, Królowa Bona (1494-1557), vol. II, Poznań 1949, pp. 49-51.

${ }^{50}$ Reverend Maciej Śliwnicki of Korab coat of arms, later the archdeacon of Gniezno and the provost of Poznan. Related to the Laskis, he studied in Bologna and perhaps also in Rome, obtaining the degree of doctor in both laws. See P. Dembiński, Śliwnicki Maciej, [in:] PSB, vol. LI, Wrocław 2016, pp. 2-6.

${ }^{51}$ Wilhelm Jarocki, household member and nephew of primate Łaski.

${ }^{52}$ L. Gładyszewski, op. cit., letter No. 2, pp. 269-270.

${ }^{53}$ It was beyond any doubt the illegitimate son of Sigismund I the Old and Katarzyna Telniczanka, later the bishop of Vilnius. 
The following letters suggest that the aim of the stay of the young Łaskis in Bologna was their common education although it is difficult to establish how closely this was connected with the university there. It is likely that they were making use of the presence of the teaching staff which was provided by the academic Bologna. Writing to his paternal uncle, Hieronim mentioned that he was aware of the primate's will that he and his brother should apply themselves to learning and continue their studies in order to ensure a better future for themselves ${ }^{54}$. Primate Easki wrote his letter of March 7, 1515 in a tone full of concern for the youths' education, expressing his joy with the progress of Jan Radziwiłl and anxiety about the attitude of Stanisław ${ }^{55}$. It is difficult to establish how long and in what personal composition the Bologna 'boarding school' functioned. It was not possible to determine this in an ambiguous manner also for Marian Chachaj, the expert on the topic, who in his work devoted to the education of the Radziwiłls suggested that Jan's stay in Bologna could have lasted till $1516^{56}$. In the case of Hieronim and Jan Łaski the preserved sources allow to recognise their further peregrinations slightly better.

\section{Going their separate ways. Further journeys made by Jan, Hieronim and Stanisław Laski}

\section{a) University path of Jan Laski}

The time spent on studies in Bologna was not crowned by obtaining scientific degrees for the Laskis, although in the case of Jan one may see certain endeavours to receive formal education. Still in 1517 he was referred to by his paternal uncle as Bononiensis scolaris who the archbishop leased the estates of Skierniewice and Łegonice as a way of providing him with financial security ${ }^{57}$. The archbishop wrote his last will and testament again probably at the beginning of 1517, appointing as its executors his chancellor Spytko of Bożenna,

${ }^{54}$ L. Gładyszewski, op. cit., letter No. 9, p. 278.

${ }^{55}$ Ibidem, letter No. 10, p. 279.

${ }^{56}$ M. Chachaj, Edukacja Radziwiłłów..., p. 15.

${ }^{57}$ The primate leased the aforementioned estates for the annual charge of 2000 florins to Jan Łaski and Mikołaj Kościelecki, the bishop of Chełm in 1517. See AGAD, BBaw, ref. code 246, sheet 30b. 
Jan Rybieński, Stanisław Borek, his Rome purser, and Jan, the Bologna student. The successors included, above all, Jarosław, the primate's brother and his nephew Hieronim ${ }^{58}$.

Earlier inscriptions did not put an end to the archbishop's endeavours aimed at securing his nephew. Using the mediation of Mikołaj Wolski, he attempted to obtain permission in the Roman Curia for conferring church positions onto his nephew, which were at the same time a source of constant income for him. In order to achieve his goal, the archbishop had to invest a hefty sum of 1400 florins as he wrote in his diary referring to it. Wolski's Rome mission was successful and on November 30, 1517 Jan obtained permission from the Pope Leo X to take up the custody of Łeczyca as well as the canonries of Cracow and Płock ${ }^{59}$. Despite this in the middle of 1518 young Łaski decided to abandon the 'Bologna school' for unknown reasons and go to a place unknown to the primate ${ }^{60}$. The nephew's decision caused his paternal uncle's dissatisfaction, which he vented in his diary, writing that he does not know who fraudulently encouraged Jan to move from the Bologna school and that he fears that his nephew will not live up to his expectations. Despite this he confirmed the prior lease of two archbishop's estates ${ }^{61}$. It remains uncertain where young Łaski went after leaving Bologna. Over the space of years suggestions appeared in historiography that his departure might have been connected with the appearances of Martin Luther in Wittenberg and the rise of the Protestant movement. Knowing the later life of Jan, the proposed concept seems quite likely. Unfortunately, it was impossible to confirm this thesis on the basis of the sources available ${ }^{62}$.

${ }^{58}$ AGAD, BBaw, ref. code 246, sheet 31 . The conclusion that the will was drafted at the beginning of the year results from the arrangement of records made by the primate in the diary. A few pages later there is information about the amount of debt and expenditure for January 27, 1517. See ibidem, sheet 33.

${ }^{59}$ AGAD, BBaw, ref. code 246, sheet 33; Vetera Monumenta Poloniae et Lithuaniae, vol. II (1410-1572), elaboration A. Theiner, Rzym 1861, No. 405, sheet 378.

${ }^{60}$ It is interesting that both in his diary and in his correspondence primate Łaski refers to Jan and his place of education exclusively as Bononiensis scolaris and Bononiensis scola. There are no terms such as studiosus, universitas or academia pointing to the university form of education of young Łaski.

${ }^{61}$ This task could be finishing his education in Bologna, even though neither its form nor the expected result remain unknown today. AGAD, BBaw, ref. code 246, sheet 38 .

${ }^{62}$ O. Bartel, op. cit., p. 73. 
Shortly after leaving Bologna, Łaski unexpectedly appeared in Padua, where he probably began his legal studies. Already on August 1, 1518 he was elected by Padua legists a council of the Polish nation, and his deputy was Maciej Polak. In Padua Jan was also mentioned on August 1, 1519, when he exchanged the functions of the representative of the Polish nation with the aforementioned Maciej ${ }^{63}$. Also at that time he failed to obtain any academic degree. He finished his stay at the university probably at the end of 1519. In January 1520 this function was taken up by Johannes Ungarus and the figure of Jan Laski ceased to appear in university records ${ }^{64}$. The precise date of the dean's return to the country remains unknown. Oskar Bartel and Hanna Kowalska claimed that he appeared in the Kingdom already in the middle of the year 1519, although regarding the information about holding certain university functions by him still in August, it seems rational to put his departure a few months forward ${ }^{65}$. Having completed his adventure in Padua he returned to the country where primate Łaski did his best to assure him some future in the church hierarchy ${ }^{66}$. Also due to his paternal uncle's endeavours he was taken into the roster of royal secretaries ${ }^{67}$. It does not seem likely, though, that working in the monarch's office corresponded to Jan's temperament and plans. As it may be presumed he was planning another journey to Italy in 1523, perhaps in order to continue his education $^{68}$. It seems highly unlikely, however, that his plans came into existence as he headed for France alongside his brother Hieronim's envoy mission in March the following year. His later journeys cannot be considered youthful peregrinations as they were initially connected with seeking his place in the world of

${ }^{63}$ Materiały do historii Polaków w Padwie, ed. S. Windakiewicz, 'Archiwum do Dziejów Literatury i Oświaty w Polsce’, vol. VII, Kraków 1892, p. 167.

${ }^{64}$ Ibidem.

${ }^{65}$ O. Bartel, op. cit., p. 79; H. Kowalska, op. cit., p. 237.

${ }^{66}$ Soon after that, upon Jan's return to the country in 1520 , the primate was trying to obtain the parishes of Gniezno and Łęczyca for his nephew, which would increase his position in the hierarchy of the chapters there and greatly improve his financial position. Three years later his paternal uncle endeavoured to obtain the function of the coadjutor of the bishop of Płock, which would pave him the way to this position after the death or promotion of Rafał Leszczyniski, the bishop.

${ }^{67}$ A. Wyczański, Między kultura a polityką. Sekretarze królewscy Zygmunta Starego (1506-1548), Warszawa 1990, p. 257.

${ }^{68}$ AGAD, BBaw, ref. code 246, sheet 40. 
humanism and humanists, and then with his commitment to the issue of the rise of European transformation.

\section{b) Knightly journey of Hieronim Laski}

It is not possible to establish unambiguously how long Hieronim stayed in Bologna. There is a presumption in the literature of the subject that he was to have appeared in Poland in 1516. The reason for this could have been the planned marriage with the daughter of Łukasz Gorka, the castellan of Poznan ${ }^{69}$. In the end the marriage plans met with failure. Under the influence of Piotr Tomicki, who was critical of the Łaskis, Łukasz Gorka did not accept the archbishop's proposal, which is reflected in the preserved correspondence between the castellan and the vice-chancellor ${ }^{70}$. In the light of the primate's failed plans one may ponder if the presence of Hieronim in the country was necessary. The lack of any source references confirming the change of his place of stay indicates that he could have been in Bologna till the end of 1516.

Probably it was not until the beginning of 1517 that Hieronim left the city and commenced a journey whose aim was to in troduce himself to foreign courts, get to know some European countries and visit 'holy places'. In the period contemporary to Laski such expeditions were quite an important element of knightly or political education. They allowed not only to substantially broaden the horizons of peregrines but they also served as a kind of auto-promotion both in the country and abroad ${ }^{71}$. In the case of Łaski this was probably another investment of his paternal uncle into the political career of his nephew. It is precisely from the primate's notes that one learns about certain details of the whole undertaking. In his diary Łaski noted that he allotted 1000 florins for his nephew to organise the

${ }^{69}$ Such a suggestion was put forward, among others, by W. Urban, op. cit., p. 225.

${ }^{70}$ Acta Tomiciana, vol. IV, ed. T. Działyński, Poznań 1855, No. 55, pp. 51-53.

${ }^{71}$ The problem of Polish educational journeys and their cultural and social significance has been attracting the attention of researchers for a long time. This resulted in such works as: J. Freylichówna, Ideał wychowawczy szlachty polskiej w XVI i poczatku XVII wieku, Warszawa 1928; W. Czapliński, J. Długosz, Podróż młodego magnata do szkót (studium z dziejów kultury XVI i XVII wieku), Warszawa 1969; A. Maczak, Życie codzienne w podróżach po Europie w XVI i XVII wieku, Warszawa 1978. 
peregrination, including bringing soldiers (pro milicia) necessary to ensure security. At the same time he warned his nephew that he should not expect any additional money. Knowing his dependant and the cost of such far-away journeys, he secured another thousand florins borrowed from Andrzej Dunin for any possible needs ${ }^{72}$. The following record concerning Hieronim in the primate's diary has the character of a will and it should be dated as of January 27, 1517. His paternal uncle allotted him from his personal belongings a scarlet tunic, perhaps ten coats of arms or other type of armaments (de armis meis propriis denatur decem nepoti Jeronimo, quator Nicolao Wolski) as well as a silver plated sword ${ }^{73}$.

In the light of the above-mentioned records it may be concluded that chronologically Hieronim's journey was between the beginning 1517 and the end of 1518 when, as the primate wrote in his diary, Hieronim informed him that he had come back safe and sound from his knightly expedition. Regrettably, its costs considerably exceeded his funds and the peregrine, staying in Venice, was asking his uncle for assistance in financing the payments due and his return journey. The nephew-loving archbishop supported Hieronim, ordering him to take out a loan in a bank on his account, as he did not know himself what amount would be sufficient ${ }^{74}$. Considering the above, it seems that Hieronim came back to the country at the beginning of 1519 , even though his stay there could not be confirmed until April $7^{75}$. It is more complicated to indicate and document the directions of his journeys. Paradoxically, this task is not facilitated by the document as of March 23, 1520 recorded in the Crown Metrica, conferring Hieronim the office of the Crown Carver: 'My, Zygmunt Król polecamy, a znajac wiadoma cnotę i owocne męstwo, wielkoduszność urodzonego i bohaterskiego Jarosława $z$ Łaska, domownika naszego, wielce nam drogiego, który od najwcześniejszych lat swoich posłuszny pierwszym rodzicielskim rozkazom, przed ukończeniem 20 roku życia, wprawiwszy się czynami wojennymi, służył na dworach książąt chrześcijańskich, docierając do Słupów Herkulesa, ziemią, a także Oceanem Śródziemnym

${ }^{72}$ AGAD, BBaw, ref. code 246, sheet 33.

${ }^{73}$ Ibidem, sheet 34b.

${ }^{74}$ Ibidem, sheet 38.

${ }^{75}$ At that time at the request of Archbishop Laski Hieronim, the Knight of the Holy Sepulchre and royal courtier, was given the house on the outskirts of Piotrków, being earlier leased to his father, Jarosław of Łask. See. AGAD, MK 34, sheet 57. 
i Morzem Północnym tak wiele przebył świata chrześcijańskiego, jak i barbarzyńskiego. Wprawiony w zgłębianiu sztuki wojennej w Galii, Prowincjach Hiszpańskich, Portugalii był zarówno sprawiedliwym i prawdziwym bohaterem, jak i pasowanym rycerzem złocistym, jerozolimskim, angielskim, afrykańskim. Świadczą o tych czynach wojennych wspomnienia, jako pomniki o dawnych królestwach, dlatego my jemu, domownikowi naszemu, uroczystym nadaniem urzędu krajczego naszego koronnego jego godne zasługi ozdabiamy $[\ldots]^{36}[\mathrm{We}$ Sigismund of Poland recommend, and knowing the evident virtue, fruitful valour and generosity of born and heroic Jarosław of Łask, our household member, so dear to us, who from his earliest years the first paternal orders obeyed, before turning 20 war deeds refined, at courts of Christian princes served, reaching the Pillars of Hercules, travelled overland and by the Mediterranean Ocean and the North Sea through so much of both the Christian and barbarian world. Skilful at learning the war art in Galia, Provinces of Spain or Portugal he both fair and true hero was as well as an accolated golden knight and knight of Jerusalem and English and African knight. These war deeds in memories reflected are, as the monuments of kingdoms of yore, hence we, by solemnly conferring him the office of the Crown Carver, his worthy merits adorn].

The quoted document, beside very clear panegyric form, contains an array of concrete information concerning Hieronim's journeys. Many researchers interpreted the document very literally, not trying to verify the content included in it $^{77}$. The basic task involves in this case establishing the circumstances of the act. It is known that it was issued in Torun on April 23, 1520. Hieronim could have been at the king's side when he was in Prussia in connection with the war activities conducted from December 1519. Returning from his peregrination to the country, he became one of royal courtiers ${ }^{78}$, and then he appeared with an eight-horse roster at a 'knight display' in $\mathrm{Cracow}^{79}$. This may not unambiguously confirm his participation

${ }^{76}$ AGAD, MK 34, sheet 290v (own translation).

${ }^{77}$ Herbarz Polski..., p. 189; W. Urban, op. cit., p. 225; R. Skowron, Dyplomaci polscy $w$ Hiszpanii $w$ XVI i XVII wieku, Kraków 1997, p. 236 (the author made references to the findings of W. Urban, op. cit., p. 225).

${ }^{78}$ On April 7, 1519 at the request of primate Laski the king conferred the court at the outskirts of Piotrków Hieronimo de Lasko, militi Hierosolymitano et curiensi nostris fideli dilecto. See AGAD, MK 34, sheet 57.

${ }^{79}$ The register was run from St Blaise's Day (February 3), 1518, the initial absence was perhaps a result of the expedition which he took part in, which is 
in the last war with the Teutonic Order, yet with this assumption the contents of the act referring to military superiorities would become more understandable. Conferring a court office to Łaski may be also connected with the endeavours of the primate who displayed considerable initiative at the time in question ${ }^{80}$. The contents of the document, particularly with regard to his possible journeys, provoke certain reservations. Regrettably, the author of this extended narration is not known although many from the royal secretaries who could have written this document were connected with the Laski family and the primate himself. Notwithstanding this, the narration contains an array of inaccuracies which hinder the perception of the source as fully reliable.

The first problematic issue involves establishing whether Hieronim served at courts of Christian princes and displayed military deeds. The completed queries both in the country and abroad did not result in finding even one trace of the Laskis at foreign courts before 1524. It seems impossible to document their stay at them, even as part of auto-presentation of young peregrines, which was common at that time. Another contentious element of the document's narration consists in identifying the places which Łaski visited as well as the titles which he received. The view that he travelled all around Europe from Great Britain to Gibraltar after which he made a pilgrimage to the Holy Land in about a year and a half is rather doubtful, which confirms the lack of more detailed information on this in the primate's notes. Another element which is worth paying attention to is the fact that among the enumerated places of Hieronim's stay there is no Italy where he stayed for at least three years (1513-1516), being at the side of his paternal uncle first in the Eternal City and then in Bologna. There is no reference to the German countries either which he must have visited during such far-reaching peregrinations. In the light of these reservations

why Hieronim does not appear in the source until 1519. See AGAD, Archiwum Skarbu Koronnego / The Crown Treasury Archive, series 85, ref. code 14, sheets 20-21.

80 This office was vacated following the resignation of Piotr Zborowski, who was given the function of the royal and court cup-bearer following the death of Stanisław Groberski. See AGAD, MK 34, sheet 292. This office acrobatics may have been initiated by primate Łaski, who accompanying the king in Torun undertook an array of activities supporting people connected with him. See AGAD, MK 34, sheets 192, 228, 240, 248. 
it is worth reconsidering where Primate Łaski's nephew might have gone in reality.

The relations of Hieronim with France and Francis I reigning there from 1515 are beyond any doubt. It seems that they should be traced back to the period of his diplomatic activity initiated in April 1520. The only possibility of an earlier encounter of the Łaskis with the king of France was the monarch's visit in Bologna in 1515. Francis and his court appeared there in order to meet with the Pope Leo X and trigger the concordat agreement. As in the case of similar events of this type, many court celebrations are likely to have taken place, including presentation of young noblemen or accolades. Known for his ability to heal the ill, Francis I was to have helped to recover another subject of Sigismund I, Mikołaj Radziwiłł, brother of Jan and Stanisław, the Laskis' companions in Bologna ${ }^{81}$. Perhaps then Hieronim was granted some honour, such as being bestowed the aforementioned title of golden knight (miles aureatus) $^{82}$. Also the information that the Laskis were to have studied at the Sorbonne in Paris is completely groundless ${ }^{83}$.

Using the title of the Knight of the Holy Sepulchre and the circumstances of the journey described in the primate's diary both support the thesis that Hieronim went on a pilgrimage to the Holy Land. The records in question suggest that young Laski came from his knightly expedition at the end of 1518. On the basis of accounts from analogous pilgrimages researchers suggested that the end of the year denoted autumn or late autumn as expeditions to Palestine tended to end between August and November ${ }^{84}$. At that time Hieronim reached Venice, a natural port which was used to

${ }^{81}$ W. Maciejewska, Mikołaj Radziwitł biskup żmudzki (1515-1529) a francuski król 'cudotwórca' Franciszek I, 'Kwartalnik Historyczny' 1938, vol. LII, pp. 226230.

${ }^{82}$ Winning spurs may have been a tradition in the Laski family. Wojciech of Łask (1396), Mojżesz of Łask (1400), Jan Łaski (1393) were accolated knights already at the turn of the $14^{\text {th }}$ and $15^{\text {th }}$ century. See A. Szymczakowa, Milites strenui $z$ sieradzkiego w XV wieku, [in:] Genealogia. Rola związków rodzinnych $i$ rodowych $w$ życiu publicznym $w$ Polsce średniowiecznej na tle porównawczym, eds A. Radzimiński, J. Wroniszewski, Torun 1996, pp. 210-212.

${ }^{83}$ In the literature of the subject there was a thesis concerning the stay of the young Łaskis in France during their educational journeys. See P. Tafiłowski, Jan Łaski..., p. 273.

${ }^{84}$ K. Ossowska, Pierwsze opisy podróży Polaków do Ziemi Świętej - wprowadzenie do badań w ujęciu geopoetyki, 'Meluzyna. Dawna Literatura i Kultura' 2014, No. 1, pp. 22-26. 
set off for the Holy Land and to return from it. Not having any sources shedding light at the very course of the pilgrimage, the researcher may only make use of analogous better documented journeys. Jan Tarnowski, probably the author of the oldest Polish diary of a pilgrimage to the Holy Land, set off for his knightly journey almost parallely. The future Grand Crown Hetman began his journey in Venice on July 4, 1518 and finished it on September 4 of the same year ${ }^{85}$. This gives us a certain picture of the logistics and space-time frame of this type of expeditions. Thanks to him it may be inferred that Hieronim, returning to Venice in autumn, set off on his expedition in June or July 1518. It also seems that the very course of the journey could have looked similar ${ }^{86}$. The fixed points of pilgrims beginning their journeys in Venice included the Greek islands of Cyprus, Rhodes, Crete, then the port in Jaffa where galleries with pilgrims docked. After reaching the place, the destination was the Church of the Holy Sepulchre in Jerusalem, Calvary, the place of birth of Jesus Christ in Bethlehem and the Church of Our Lady there. Pilgrimages were also made to Mount Sinai, where one could obtain the title of St. Catherine's Knight in the local monastery and to the Jordan River to commemorate Christ's baptism ${ }^{87}$. The repetitive character of pilgrimage routes allows to presume that it did not differ much in the case of Hieronim. It is certain that he visited the Church of the Holy Sepulchre, where the guardian of the Mount Zion Temple accolated him the knight of the Holy Sepulchre, with which title Laski returned to the country in $1519^{88}$.

85 The Herman's diary indicates that Tarnowski left Venice on July 4, reaching the port in Jaffa, on August 14 he began the proper part of his stay in the Holy Land which lasted till September 4. See D. Chemperek, Dziennik podróży Jana Tarnowskiego do Ziemi Świętej z 1518 roku, 'Odrodzenie i Reformacja w Polsce' 2005, vol. XLIX, p. 187.

${ }^{86}$ Katarzyna Ossowska made a synthesis on the basis of the preserved accounts of pilgrimages to the Holy Land in the modern era. See K. Ossowska, op. cit., pp. 22-26.

${ }^{87}$ The place in question was visited by Jan Długosz during his pilgrimage. See J. Bystroń, Polacy w Ziemi Świętej, Syrii i Egipcie, Kraków 1930, p. 8; Jan Tarnowski - D. Chemperek, Dziennik podróży Jana Tarnowskiego..., pp. 187194; probably Jan Dantyszek - J. Bystroń, op. cit., p. 12 or Mikołaj Sierotka Radziwiłł - H. Lulewicz, Radziwiłt Mikołaj zwany Sierotka, [in:] PSB, vol. XXX, Wrocław 1987, pp. 349-361.

${ }^{88}$ The description of the ceremony of conferring the title of the knight of the Holy Sepulchre of Jerusalem was presented by Jan Tarnowski in his diary. It is a reliable account since its source is the Herman's own experience. It also seems 
In the search of further analogies it is worth pointing out that Jan Tarnowski, having completed his pilgrimage to the Holy Land in September 1518, went, according to Stanisław Orzechowski, his biographer, on his knightly journey overland through Egypt to the port in Alexandria, then to Greek Athens, Portugal in order to get to England through Spain and France from which he set off on his journey back to the country, visiting Germany and Bohemia on his way ${ }^{89}$. The biography of Tarnowski written by his apologist arises doubts in some places. As for the expedition of the future hetman, the variety of additional sources allows to confirm or increase the credibility of certain journey stages $^{90}$. The situation looks much worse in the case of Hieronim's peregrination. The preserved documents, chronicles and correspondence which could have mentioned Laski are all silent about this.

The researcher is faced with such a situation while verifying the stay of Hieronim in Portugal and his possible participation in fights with the Moors in North Africa. The chronicle of the reign of the Portuguese monarch, Emmanuel I, by Damiao de Góis which refers to the time of Łaski's peregrinations is probably the only non-Polish testimony of Hieronim's fellow-countrymen's stay in the surroundings of king Emmanuel who reigned between 1495 and $1521^{91}$. The information given by the author about the visitors from the Kingdom of Poland do not concern, however, Hieronim Laski.

Tego roku [1516] przybyli do królestwa trzej szlachcice polscy, z których najważniejszym był Jan Tarnowski ${ }^{92}$. Głównym powodem

that O. Bartel was wrong, claiming that Hieronim was granted this honour from the hands of the Pope, when he was in Rome in 1513. See O. Bartel, op. cit., p. 71. It is impossible to sustain the thesis of S. Malinowski, repeated by W. Zakrzewski and J. Sikorski, that Hieronim was accompanied by Stanisław on his journey to the Holy Land. The youngest of the brothers did not hold the title of the knight of the Holy Sepulchre until 1531. See AGAD, MK 47, sheet 24.

${ }^{89} \mathrm{~S}$. Orzechowski, Żywot $i$ śmierć Jana Tarnowskiego: kasztelana krakowskiego, hetmana wielkiego koronnego, ed. F. Bohomolec, Sanok 1855, pp. 46-51.

${ }^{90}$ W. Dworzaczek, Hetman Jan Tarnowski. $Z$ dziejów możnowładztwa małopolskiego, Warszawa 1985, pp. 17-22; Z. Spieralski, Jan Tarnowski 14881561, Warszawa 1977, pp. 78-83.

${ }^{91}$ D. de Góis, Kronika wielce szczęśliwego króla dom Manuela (1495-1521), elaboration and transl. J.Z. Klave, Warszawa 1989.

${ }^{92}$ The date given by the author of the chronicle is wrong. Also W. Dworzaczek pointed to this, making a reference to a letter of May 9, 1518 from Sigismund I recommending Jan Tarnowski to Emmanuel I. See W. Dworzaczek, Hetman Jan Tarnowski..., p. 21. 
ich przybycia była prośba, aby król swą ręką pasował ich na rycerzy, a prosili o ten honor $\mathrm{z}$ powodu sławy, jaka się cieszył $\mathrm{w}$ stronach, $z$ jakich pochodzili i w sąsiednich [...]. Prośbie tych szlachciców król łatwo uczynił zadość i okazał swoje zadowolenie. Rozkazał, aby uroczystość odbyła się w kościele św. Jana w Lizbonie, a brali w niej udział wszyscy panowie obecni na dworze, wielu ze szlachty i rycerstwa. Mogę zapewnić, że byli bardzo zadowolenie ci trzej szlachcice $z$ powodu łask i honorów, jakie na nich spadły od króla, $z$ dobrego przyjęcia, jakiego doznali od niektórych szlachciców, a to dlatego że tenże Jan Tarnowski i inni panowie i szlachta bardzo gościnnie mnie przyjęli w latach 1529 i 1531, kiedy dwukrotnie, na rozkaz króla D. Joao III, byłem na dworze króla Polski Zygmunta I93. [That year [1516], three Polish noblemen fared forth the Kingdom, and the most important amid them was Jan Tarnowski. They peregrinated to conjure the king to accolade them with his own hand, and they asked for this honour for the fame the king in their country and neighbouring lands rejoiced [...]. The king granted the noblemen's plea, his contentment showing hereupon. He adjured a ceremony in St. John's Church in Lisboa, and in it partook all the men at the court, with many noblemen and knights. I quoth these three noblemen most rejoiced with all the favours and honours the king on them bestowed, the warm welcome from some noblemen, and 'tis due to the cordiality Jan Tarnowski and other noblemen showed me in 1529 and 1531, when at the court of the Polish king, Sigismund I twice I was on the orders of king D. Joao III].

The work which the quoted fragment comes from was probably written in the sixties of the $17^{\text {th }}$ century. Consequently, the chronicle is retrospective in character and not all the content included in it results from the author's observations. Damião de Góis lived between 1502 and 1574. According to researchers, as a sixteen-year-old young man he stayed at the royal court during the stay of the Poles in Lisboa. It is more probable, though, that he got to know about this during his journeys to the Kingdom of Poland between 1529 and 1531. During one of them he was to meet Jan Tarnowski in person, and perhaps also other crown magnates ${ }^{94}$. It is difficult to imagine, therefore, that while including the figure of the Polish hetman in his chronicle, he could have omitted Hieronim Łaski, probably one of the most prominent politicians of his day, if

${ }_{93}$ D. de Góis, op. cit., pp. 307-308.

${ }^{94}$ Ibidem, pp. 5-7. 
he had visited Portugal like Tarnowski. It is all the more unlikely that that de Góis spent about six months of 1534 with Erasmus of Rotterdam in Freiburg. Knowing the relations of the famous humanist with the Laski family, it is difficult to believe that the figure of Hieronim was not known to the Portuguese author. This does not naturally exclude the fact that Laski visited Portugal but it suggests that he could have not displayed any particular military superiority there, as they would have been included in the chronicle of Damião de Góis.

Thus it is worth summarising the knowledge on the knightly expedition of Hieronim Łaski which may have lasted from early spring 1517 till late autumn of 1518. Staying in Venice, Bologna and Rome, he must have got to know Italy quite well. He is certain to have made a pilgrimage to the Holy Land, perhaps reaching also Egypt and Syria. He was certainly familiar with the German countries and Vienna, the capital of the empire, which he visited on his way to Italy and possibly back home. The remaining directions of Łaski's peregrinations remain uncertain. There is hope that future research queries will allow to obtain materials allowing to solve at least part of these puzzles. Referring only to one document, it is difficult to produce credible statements concerning youthful peregrinations of Hieronim.

\section{c) On Stanisław Laski's journeys}

The figure of the youngest of the kaskis and his youth raise the greatest doubts even though they are described in the literature of the subject. The first problem which was mentioned above is connected with difficulties in establishing the date of birth of Stanisław. Due to the lack of new sources it seems groundless to point to any concrete date. One may risk, however, to situate it after 1503 or 1504 . Assuming that this thesis is correct at the time of the aforementioned primate's journey to Rome and the subsequent Italian period of education of Jan and Hieronim, the absence of Stanisław may be explained by his young age. There is not a single source reference which would allow to suppose that the youngest of three brothers studied with the others in Bologna or, as it was argued by some researchers, went there later with Mikołaj Wolski. H. Dalton was the first to put forward such 
a thesis, claiming that he was too young to set off for Rome with the others in 1513, which is why he joined his brothers in the retinue of Castellan Wolski returning from Orsha in $1515^{95}$. It would not be a particularly fanciful theory if it had not been for the fact that the preserved correspondence from Bologna illustrates the composition of the Polish house in Bologna, also after the arrival of Wolski, Jan Laski and Stanisław Radziwiłł ${ }^{96}$. It seems that the very figure of Stanisław Radziwiłł is the key to the mistake made by Dalton. The same first name and occurrence in the sources of the song of the voivode of Vilnius without his family name could have caused the researcher focused on the Easkis to merge these two figures into one, creating his thesis on the Bologna studies of Stanisław Łaski.

The literature of the subject also abounds in assertions about special bonds of the youngest brother with France and the court of Francis I of France. The majority of theses on this topic is based on one quite peculiar source, namely the preserved speech of the French envoy Francis Baldwin to Jan Zamoyski from 1573. The work was a poetic form of response to the Polish legation to Henry III of France led by Olbracht Łaski, Hieronim's son. Talking about the political artistry of the Polish and proclaiming their legation above other historical legations known to him, Baldwin referred to both the Cracow university as a nugget of culture and the greatness of the dynasty as well as grandeur of individuals. He directed one of the verses of his speech to Olbracht Laski, mentioning that he witnessed 'gdy dziad Alberta Łaskiego na czele niniejszego poselstwa $z$ senatu świeckiego będący, wszystkich trzech synów swoich we Francji wychował. Najstarszy $z$ tych, Hieronim prawie od samego Franciszka I króla był pielęgnowany. Hieronim znajdował się $z$ nim na nieszczęśliwej bitwie pod Pawią we Włoszech i po tym nieodstępnie niewolę w Hiszpanii dzielił' [when Albert Łaski's grandfather leading this legation, from secular senate being, all

\footnotetext{
${ }^{95}$ H. Dalton, op. cit., p. 54.

${ }^{96}$ Regrettably, H. Dalton's findings have not been properly verified yet and the following researchers repeated the thesis about Bologna education of Stanisław Łęcki which is not confirmed by the sources. In different time variants, making references to the works of the researcher in question, this information was perpetuated by: J. Korytkowski, op. cit., pp. 499-501; A. Hirschberg, Hieronim Łaski..., p. 6; O. Bartel, op. cit., p. 71; J. Sikorski, op. cit., p. 253; P. Tafiłowski, Jan Łaski..., p. 270; A. Kamler, Od szkoły do senatu. Wykształcenie senatorów $w$ Koronie w latach 1501-1586. Studia, Warszawa 2006, p. 298.
} 
his three sons in France raised. Nigh Francis I himself nursed the eldest one, Hieronim who with him was during the miserable Battle of Pavia in Italy and his captivity in Spain inseparably shared $]^{97}$.

The information included in the fragment above was sufficient to create a thesis on the Paris studies of the Laski brothers, earlier stay of Jan and Hieronim at the court of Francis I and their war artistry mastered at the side of the French monarch ${ }^{98}$. Little was needed to criticise the source and verify the information included in it. The basic issue is the panegyric form of Baldwin's speech which by definition was supposed to create a hyperbolic picture of supremacies of the Polish legation and the Kingdom of Poland as such. Presentations of envoys and their relations with the author's country were subject to similar treatment. As the legation was led by Olbracht, Hieronim's son, it was precisely his father that was to be presented in favourable light. It is worth referring to the author himself and his knowledge on the events which he was describing. Born in 1520 Francis had no opportunity to meet the young Łaskis when they visited France, which is why the claims about the autopsy character of the narration seem erroneous ${ }^{99}$. Another doubtful element is the claim that Jarosław, the voivode of Sieradz, father of the Laskis, sent all his three sons to study in France. This is contradicted by the preserved sources, clearly defining education places and time of Jan and Hieronim. The last element which is difficult to agree with involves pointing to Hieronim as a participant of the Battle of Pavia fought by Francis I of France and a prisoner of the Emperor Charles V since it is known that at that time Hieronim stayed in the country, taking part, for instance, in the homage of Albrecht Hohenzollern in Cracow ${ }^{100}$.

${ }^{97} Z$ mowy Franc. Baldwina do Jana Saryusza Zamoyskiego (Polish translation by Józef Max. Hr. Ossoliński), 'Czasopism Naukowy Księgozbioru Publicznego im. Ossolińskich' 1830, vol. III, issue 1, p. 10.

${ }^{98} \mathrm{M}$. Malinowski (op. cit., p. XVII) went the furthest in his hypotheses concerning the stay of the Łaskis in France, claiming, for instance, that Stanisław was at the court of Francis I of France twice, between 1516-1518 and 1524-1527. Other historians quoted Baldwin, wanting to see the young Łaskis studying in France. See C. Walewski, Jan Łaski, reformator Kościoła. Wiadomość historyczno-bibliograficzna, 'Biblioteka Warszawska', vol. II, Warszawa 1872, p. 358 and P. Tafiłowski, Jan Łaski..., p. 273. The first researcher to oppose these proposals was A. Hirschberg, Hieronim Łaski..., p. 7.

${ }_{99}^{9}$ N.A. Weber, Francis Baldwin, [in:] The Catholic Encyclopedia, vol. II, New York 1913, p. 221.

${ }^{100}$ A. Hirschberg, Hieronim Łaski..., pp. 40-43. 
The aforementioned array of doubts does not make, however, that Baldwin's account is valueless as a source for the topic in question. It is a fact that all three brothers appeared in France at the court of Francis I of France. The character of this visit, however, was different. Hieronim, acting from 1520 as an envoy of Sigismund I, visited monarch courts which were the aim of his diplomatic missions. He was sent to France in 1524, which is confirmed by letters of recommendation and envoy instructions ${ }^{101}$. The expedition to Paris turned out to be a good pretext to take Jan and Stanisław with him. The presence of all the Laskis in the envoy retinue may be inferred on the basis of preserved sources. In this respect the letters by Erasmus of Rotterdam, who hosted all three brothers when they were staying in Basel on their way to the court of Francis I of France.

The fame of the humanist of Rotterdam caused that numerous supporters of his views and curious of his person 'made pilgrimages' to him. Hieronim, having got to know Erasmus during his first legation in 1520, probably wished that his brothers also had an opportunity to meet him. We learn about Laski's stay in Basel from the humanist's letter to Stanisław Turzon, the archbishop of Olomouc of November 21, 1521. In his correspondence Erasmus mentioned that the Polish envoy visited him and, as it may be presumed, made a very good impression on him ${ }^{102}$. This time the Easkis arrived in Basel probably at the turn of March and April as at the end of that month Hieronim reached Blois where Francis I was staying with his court ${ }^{103}$. The envoy returned to the country in October 1524 when Erasmus wrote a letter to Hieronim Laski in which he recalls the stay of the Easkis in Basel: 'Tak oto tam i z powrotem wędrują dary Gracji, najsławniejszy mężu, Hieronimie. Pozostawiłeś w moim domu zastaw, świadczacy o Twojej do mnie miłości, a teraz z kolei przybywa do Ciebie poświadczenie moich wzajemnych uczuć. [...] Jeśli znajdzie on Twoje uznanie, zechciej

${ }^{101}$ Poselstwo do króla francuskiego przez Hieronima Łaskiego odbyte, 1523, Biblioteka Kórnicka PAN / The Kórnik Library of PAS, ref. code 245, print: Acta Tomiciana, vol. VI, ed. T. Działyński, Poznań 1857, No. 190, pp. 207-209; J.U. Niemcewicz, Zbiór pamiętników historycznych o dawnej Polszcze, vol. IV, Warszawa 1822, pp. 21-26.

102 Opus epistolarum Des. Erasmi Roterodami, ed. P.S. Allen, vol. IV (15191521), Oxford 1922, n. 1242.

${ }^{103}$ A. Hirschberg, Hieronim Easki..., p. 30. 
zawiadomić o tym Twoich braci Jana i Stanisława [...] ${ }^{104}$ [And thus to and fro gifts of Grace arrive, Hieronim, most far-famed man. Thou a pledge in my house left, which speaketh of thy love to me, and now in turn is proof of my mutual feelings sent. (...) If thy praise it wins, advise your brothers, Jan and Stanisław].

Visits paid to Erasmus by the Laskis resulted in abundant correspondence, part of which is preserved to the present day. Jan Easki certainly developed the closest bond with Erasmus as he spent many months at the side of the famous humanist, maintaining his house and servants at that time. The dean of Gniezno was also not unfamiliar with France since it was there where he met talented and willing to learn young Agnanus Bourgion, also called Anianus Burgonius, who left his country together with Łaski in 1525 and accompanied him to his unexpected death in $1535^{105}$. Stanisław appeared in Erasmus's letters the least, yet while exchanging correspondence with the other brothers, the humanist tended to ask about the youngest of them and greeted him cordially ${ }^{106}$.

It seems that it is precisely the journey with his brothers that was some kind of peregrination for Stanisław which he could not accomplish, according to the sources, together with his elder siblings. Having left the country in March 1524, he had the opportunity to meet one of the greatest contemporary minds and visit Western Europe. Together with his brother he also had the opportunity to get to know the surroundings of Francis and observe in practice the envoy mission realised by Hieronim. It seems that the French court became a particularly interesting and friendly place for Stanisław as he decided to stay there longer as a royal courtier. We learn about his activities there from the book attributed to him Ksiegi o gotowości wojennej [Books about War Readiness], in which the author repeatedly recalls his battle adventures at the side of Francis I as well as participation in the famous Battle of Pavia: '[...] Nie mamy pierwej o miasto czy zamek się kusić, pokąd ziemie a krainy wszego onego miejsca nie opanujemy, o które się chcemy pokusić, bo na tym wiele a niemało zależy. Spytać by nas cośmy przy Królu francuskim pod Pawią doświadczali. Mieć w zanadrzu węża,

${ }^{104}$ Korespondencja Erazma $z$ Rotterdamu z Polakami..., No. II, p. 23.

${ }^{105}$ S. Kot, Polska złotego wieku. Studia i szkice, elaboration H. Barycz, Warszawa 1987, p. 147.

${ }^{106}$ Korespondencja Erazma $z$ Rotterdamu $z$ Polakami..., No. XVIII, LXXVIII, pp. 78-81, 271-272. 
wierz mi że nikt nie wie, jedno ów co go nosi' [... Ere are we not to be tempted to get the city or castle till all the land and country we conquer which we were tempted to get, for much depends on it. Ask us what we with the king of France at Pavia underwent. To hold back a serpent knows only that who the serpent hath, methinks] ${ }^{107}$.

Another source illustrating the 'French period' of Łaski is an elegy written by Bernhard Holtorp ${ }^{108}$. The character of quoted sources, especially the aforementioned elegy, requires in my opinion a separate analysis and in-depth criticism of the source. This will not be possible without a scientific query in French archives where there might be some materials concerning Laski's stay at the court of Francis I. This is not, however, the purpose of this article. In order to preserve certain order it should be pointed out that the specific knightly education which Stanisław received at the French court, probably lasted till spring 1527. In his letter of May 17 of that year addressed to Jan Łaski Erasmus of Rotterdam expressed his joy at the happy comeback of Stanisław from France ${ }^{109}$. The youngest of brothers spent the following years on numerous journeys connected with Hieronim's international activity, supporting his endeavours in Hungary or managing his Špis estate. One may presume that the education of Laski during his youthful journeys was not in vain. He could use his knowledge and experience in his diplomatic missions whose analysis, like the biography of Stanisław Łaski, still requires research, which may be considered to be the present research postulate.

\section{Bibliography}

\section{Archival sources}

Archiwum Główne Akt Dawnych w Warszawie [AGAD]

(The Central Archives of Historical Records in Warsaw)

Archiwum Skarbu Koronnego / The Crown Treasury Archive, series 85, ref. code 14.

${ }^{107}$ Księgi pierwsze. Nauka Jana Tarnowskiego o gotowości wojennej, [in:] Stanisława Łaskiego wojewody sieradzkiego prace naukowe..., pp. 3-139.

${ }^{108}$ B. Holtorp, De peregrinatione magnifici ac generosi domini Stanislai a Lasco, equitis aurati, palatini Siradiensis, capitanei Lanciciensis, etc., liber primus, Monte Regio 1548.

${ }^{109}$ Korespondencja Erazma z Rotterdamu z Polakami..., No. XVIII, pp. 79-81. 
Metryka Koronna [MK] / The Crown Metrica 34, 37, 47.

Varia $z$ Biblioteki Baworowskich [BBaw] / Varia from Bawarowscy Library, ref. code 246.

Biblioteka Kórnicka PAN

(The Kórnik Library of PAS)

Poselstwo do króla francuskiego przez Hieronima Łaskiego odbyte, 1523, manuscript, ref. code 245 .

\section{Printed sources}

Acta Tomiciana, vol. IV, ed. T. Działyński, Poznań 1855.

Acta Tomiciana, vol. VI, ed. T. Działyński, Poznań 1857.

Akta synodów różnowierczych w Polsce, vol. II (1560-1570), elaboration M. Sipayłł, Warszawa 1972.

Chemperek D., Dziennik podróży Jana Tarnowskiego do Ziemi Świętej z 1518 roku, 'Odrodzenie i Reformacja w Polsce' 2005, vol. XLIX, pp. 183-194.

Gładyszewski L., Korespondencja studentów bolońskich z prymasem Janem Łaskim w 1515 roku, 'Studia Gnesnensia' 1997, vol. III, pp. 261-280.

Góis D. de, Kronika wielce szczęśliwego króla dom Manuela (1495-1521), elaboration and transl. J.Z. Klave, Warszawa 1989.

Herbarz Polski, part 1 (Wiadomości historyczno-genealogiczne o rodach szlacheckich), eds Boniecki, A. Reiski, vol. XV, Warszawa 1912.

Herby rycerstwa polskiego przez Bartosza Paprockiego zebrane i wydane r. p. 1584, ed. K.J. Turowski, Poznań 1859.

Holtorp B., De peregrinatione magnifici ac generosi domini Stanislai a Lasco, equitis aurati, palatini Siradiensis, capitanei Lanciciensis, etc., liber primus, Monte Regio 1548.

Korespondencja Erazma $z$ Rotterdamu $z$ Polakami, transl. and elaboration M. Cytowska, Warszawa 1965.

Materiały do historii Polaków w Padwie, elaboration S. Windakiewicz, 'Archiwum do Dziejów Literatury i Oświaty w Polsce', vol. VII, Kraków 1892, pp. 149-186.

Metrica nec non liber nationis Polonicae Universitatis Lipsiensis ab anno 1409 usque ad 1600, ed. S. Tomkowicz, 'Archiwum do Dziejów Literatury i Oświaty w Polsce', vol. II, Kraków 1882, pp. 409-467.

Niemcewicz J.U., Zbiór pamiętników historycznych o dawnej Polszcze, vol. IV, Warszawa 1822.

Opus epistolarum Des. Erasmi Roterodami, ed. H.M. Allen, vol. IV (1519-1521), Oxford 1922.

Opus epistolarum Des. Erasmi Roterodami, ed. H.M. Allen, vol. VII (1527-1528), Oxford 1928.

Orzechowski S., Żywot i śmierć Jana Tarnowskiego: kasztelana krakowskiego, hetmana wielkiego koronnego, ed. F. Bohomolec, Sanok 1855.

Stanisława Łaskiego wojewody sieradzkiego prace naukowe $i$ dyplomatyczne, ed. M. Malinowski, Wilno 1864. 
Starowolski S., Sarmatiae Bellatores, Kolonia 1631.

Unieszowski J., Evdimonia Olbrichta Laskiego woiewodi siradzkiego, Kraków 1609.

Vetera Monumenta Poloniae et Lithuaniae, vol. II (1410-1572), elaboration A. Theiner, Rzym 1861.

$Z$ mowy Franc. Baldwina do Jana Saryusza Zamoyskiego (Przekład polski Józefa Max. Hr. Ossolińskiego), 'Czasopism Naukowy Księgozbioru Publicznego im. Ossolińskich’ 1830, vol. III, issue 1, pp. 1-14.

Zeissberg H., Johannes Easki Erzbischof von Gnesnen (1510-1531) und sein Testament, [in:] Sitzungsberichte der Philosophisch-Historischen Klasse der kaiserlichen Akademie der Wissenschaften, Bd. LXXVII, Hf. III, Wien 1874, pp. 517-735.

\section{STUdies}

Bartel O., Jan Łaski, part 1 (1499-1556), Warszawa 1955.

Bartels P., Johanes a Lasco, Elberfeld 1860.

Barycz H., Przybyło Maciej, [in:] Polski słownik biograficzny, vol. XXIX, Wrocław 1986, pp. 122-123.

Barycz H., Pociecha W., Borek Stanisław, [in:] Polski słownik biograficzny, vol. II, Kraków 1936, pp. 320-322.

Bystroń J., Polacy w Ziemi Świętej, Syrii i Egipcie, Kraków 1930.

Chachaj M., Młodość Michała Tomasza Korybuta Wiśniowieckiego przyszłego króla polskiego, 'Czasy Nowożytne' 2015, vol. XXVIII, pp. 95-111.

Chachaj M., O dacie urodzenia $i$ edukacji hetmana Jana Karola Chodkiewicza, [in:] Studia z dziejów Wielkiego Księstwa Litewskiego (XVI-XVIII wieku), eds S. Górzyński, M. Nagielski, Warszawa 2014, pp. 49-59.

Chachaj M., Zagraniczna edukacja Radziwiłłów od początku XVI do połowy XVII wieku, Lublin 1995.

Czapliński W., Długosz J., Podróż młodego magnata do szkół (studium z dziejów kultury XVI i XVII wieku), Warszawa 1969.

Dalton H., Johannes a Lasco Beitrag zur Reformationsgeschichte Polens Deutschlands und Englands, Gotha 1881.

Dalton H., John a Lasco. His earlier life and Labours, transl. J. Maucrice, B. Evans, London 1886.

Dembiński P., Śliwnicki Maciej, [in:] Polski słownik biograficzny, vol. LI, Wrocław 2016, pp. 2-6.

Dworzaczek W., Hetman Jan Tarnowski. Z dziejów możnowładztwa małopolskiego, Warszawa 1985.

Dworzaczek W., Łaski Jan, [in:] Polski słownik biograficzny, vol. XVIII, Wrocław 1973, pp. 229-237.

Freylichówna J., Ideał wychowawczy szlachty polskiej w XVI i początku XVII wieku, Warszawa 1928.

Hirschberg A., Hieronim Łaski, Lwów 1888. 
Hirschberg A., Jan Łaski. Arcybiskup gnieźnieński sprzymierzeńcem sułtana tureckiego. Szkic historyczny, Lwów 1879.

Kamler A., Od szkoły do senatu. Wykształcenie senatorów $w$ Koronie $w$ latach 15011586. Studia, Warszawa 2006.

Kłaczewski W., Jerzy Ossoliński. Wielki kanclerz Rzeczypospolitej, Lublin 2011.

Korytkowski J., Prałaci i kanonicy katedry metropolitalnej gnieźnieńskiej od roku 1000 do dni naszych, vol. II, Gniezno 1883.

Kot S., Polska złotego wieku. Studia i szkice, elaboration H. Barycz, Warszawa 1987.

Kowalska H., Łaski Jan, [in:] Polski słownik biograficzny, vol. XVIII, Wrocław 1973, pp. 237-244.

Kraushar A., Olbracht Laski wojewoda sieradzki. Wizerunek historyczny na tle dziejów Polski XVI wieku, Warszawa-Kraków 1882.

Lulewicz H., Radziwiłt Mikołaj zwany Sierotka, [in:] Polski słownik biograficzny, vol. XXX, Wrocław 1987, pp. 349-361.

Maciejewska W., Mikołaj Radziwiłł biskup żmudzki (1515-1529) a francuski król 'cudotwórca' Franciszek I, 'Kwartalnik Historyczny' 1938, vol. LII, pp. 226-428.

Małecki A., Gramatyka historyczno-porównawcza języka polskiego, vol. I, Lwów 1879.

Mączak A., Życie codzienne w podróżach po Europie w XVI i XVII wieku, Warszawa 1978.

Ossowska K., Pierwsze opisy podróży Polaków do Ziemi Świętej - wprowadzenie do badań w ujęciu geopoetyki, 'Meluzyna. Dawna Literatura i Kultura' 2014, No. 1, pp. 21-33.

Pociecha W., Branicki Jan, [in:] Polski słownik biograficzny, vol. II, Kraków 1936, p. 402.

Pociecha W., Królowa Bona (1494-1557), vol. II, Poznań 1949.

Pociecha W., Ze studiów bolońskich Jana Łaskiego, 'Reformacja w Polsce' 1926, vol. IV, pp. 143-152.

Sikorski J., Łaski Stanisław, [in:] Polski słownik biograficzny, vol. XVIII, Wrocław 1973, pp. 253-255.

Skowron R., Dyplomaci polscy w Hiszpanii w XVI i XVII wieku, Kraków 1997.

Spieralski S., Jan Tarnowski 1488-1561, Warszawa 1977.

Szymczakowa A., Milites strenui z sieradzkiego w XV wieku, [in:] Genealogia. Rola zwiąków rodzinnych $i$ rodowych $w \dot{z} y c i u$ publicznym $w$ Polsce średniowiecznej na tle porównawczym, eds A. Radzimiński, J. Wroniszewski, Toruń 1996, pp. 191-215.

Tafiłowski P., Finanse prymasa Jana Laskiego. Na podstawie raptularza $z$ Archiwum Głównego Akt Dawnych w Warszawie, 'Przegląd Historyczny' 2004, vol. XCV, issue 1, pp. 1-36.

Tafiłowski P., Jan Łaski (1456-1531) kanclerz koronny i prymas Polski, Warszawa 2007.

Trawicka Z., Jakub Sobieski (1591-1646). Studium z dziejów warstwy magnackiej w Polsce doby Wazów, Kraków 2007. 
Urban W., Łaski Hieronim, [in:] Polski słownik biograficzny, vol. XVIII, Wrocław 1973, pp. 225-229.

Urzednicy wielkopolscy XVI-XVIII wieku. Spisy, elaboration A. Bieniaszewski, Wrocław 1987.

Walewski C., Jan Łaski, reformator Kościoła. Wiadomość historyczno-bibliograficzna, 'Biblioteka Warszawska', vol. II, Warszawa 1872, pp. 358-391.

Weber N.A., Francis Baldwin, [in:] The Catholic Encyclopedia, vol. II, New York 1913, p. 221.

Witusik A., Młodość Tomasza Zamojskiego. O wychowaniu $i$ karierze syna magnackiego $w$ pierwszej połowie XVII wieku, Lublin 1977.

Wyczański A., Między kultura a polityką. Sekretarze królewscy Zygmunta Starego (1506-1548), Warszawa 1990.

Zajączkowski S.M., Łaski Jarosław, [in:] Polski słownik biograficzny, vol. XVIII, Wrocław 1973, pp. 244-245.

Zakrzewski W., Rodzina Łaskich w XVI wieku. II. Synowcowie prymasa: reformator Jan Łaski i jego bracia Hieronim i Stanisław, 'Ateneum' 1882, vol. IV, pp. 554-559.

MARCIN JANAKOWSKI

\section{Między faktami a panegiryzmem. Śladami młodzieńczych lat i peregrynacji Hieronima, Jana i Stanisława Laskich}

\footnotetext{
$Z$ ainteresowanie badawcze rodziną Łaskich herbu Korab przyniosło szereg interesujących prac oraz wielokrotnie więcej postulatów i pytań badawczych. Powstałe na przełomie XIX i XX w. opracowania wymagaja dziś aktualizacji i uzupełnienia. Dotyczy to tak kwestii faktograficznych, jak i interpretacyjnych. $\mathrm{W}$ artykule autor podejmuje próbę realizacji tych postulatów $\mathrm{w}$ odniesieniu do czasu edukacji i peregrynacji trzech przedstawicieli rodziny $z$ Łaska: Hieronima, Jana i Stanisława, synów Jarosława i Zuzanny z Bakkowej Góry, bratanków zaś kanclerza i prymasa Jana Łaskiego. Obok rekonstrukcji wydarzeń dokonano ponownej interpretacji zachowanego materiału źródłowego i zestawiono otrzymane wyniki $z$ dotychczasowym stanem badań. Efektem tego zabiegu jest wskazanie powtarzanych przed dekady nieścisłości lub niemających ugruntowania źródłowego twierdzeń, które utrwaliły się w dotychczasowej historiografii.
}

Słowa kluczowe: Łaski, peregrynacja, studia, Bolonia, Wenecja. 